\title{
Several "Organic" Vineyards, Manuered And Fertilized With Special Cover Crops, Produce Organic Wine: Its Habitual Consumption Can Result Letal To Man.
}

\author{
*Lorenzo Martini \\ Department of Pharmaceutical Biotechnologies University of Siena \\ *Corresponding Author: Lorenzo Martini
}

\begin{abstract}
It is my specific intention to demonstrate that "Organic wine", that has imposed a crucial fashion in several countries of all over the world, letting its cost grow hawful, may be severally perilous for Human Health, since the cover crops used to manure roots of vine can contain, beside hay or trifolium, even vetch, lupins and faba vicia minor (field beans), that contain vicine, a glycoside that can drive to anemia, favism and finally, if not tempestively treated, death of the habitue of wine tasting or drinking.

I have detected great percentages of vicine in the fresh young leaves, in the first unripe grapes and finally in the Organic wine itself that was manured with lupins, vetch and field beans.
\end{abstract}

Keywords: Organic wine, death by, favism, vetch, cover crops, lathyrism

Date of Submission: 13-07-2017

Date of acceptance: 22-07-2017

\section{Background}

Vineyard cover cropping practices have been refined in manifold countries especially overseas over the past 15 years.

Nowaday Organic wine has become an invincible and irriducible fashion (in many countries, for instance Italy and France, Spain and USA, and it has grown as an hysterical phenomenon).

When organic and sustainable winegrowing began in the late 1980s, many of the cover crop species were selected from agronomic crop farming systems. While these were well-suited for bringing "life" back into the soil, they weren't ideal species for a vineyard. Many were simply too energy-intensive to farm; too vigorous, grew into the trellis, produced too much biomass to manage easily, or produced too much nitrogen in the soil.

Organic winegrowers do not use any herbicides or synthetically processed concentrated fertilizers. They rely on compost for nutrients. (Compost also makes a significant contribution to the goal of building soil carbon, as it contains fairly stable humus-like compounds.)

There is the common tendency to assert that a cover crop is simply a non-cash crop - like clover, peas, or oats - planted in addition to a cash crop, like grapes or corn, in fallow fields or between vine rows. Mostly grasses and cereal grains, these crops often look like boring green carpeting, but are really Mother Nature's secret weapon for restoring soil vitality and increasing biodiversity. And unlike the chemical fertilizers that dominate in America's farmlands, cover crops are organic and don't contribute to toxic streams of runoff.

Too many viticulturists oftenuse cover crops that are made of hay or Foin de Crau but they employ even Legumes (Lathyrus sativus) or Fabaceae (Field bean or Faba vicia minor), Lupin (Lupinus albus), Vetch (Vicia sativa) and all these plants contain a modest percentage of two perilous glycosides, vicine and convicine, (from 2 till 7\%) that can lead to perniciosa anaemia, favism and finally, if not cured adequately, they can result letal for Human Health.

Lathyrus spp. maydrive to lathyrism, that is a neurological disease of humans and domestic animals, caused by eating certain legumes of the genusLathyrus. This problem is mainly associated with Lathyrus sativus (also known as Grass pea, Kesari Dal, Khesari Dal or Almorta) and to a lesser degree with Lathyrus cicera, Lathyrus ochrus and Lathyrus clymenum, containing the toxin ODAP.

The consumption of large quantities of Lathyrus grain containing high concentrations of the glutamate analogue neurotoxin $\beta$-oxalyl-L- $\alpha, \beta$-diaminopropionic acid (ODAP, also known as $\beta$-N-oxalylamino-L-alanine, or BOAA) causes paralysis, characterized by lack of strength in or inability to move the lower limbs, and may involve pyramidal tracts producing signs of upper motor neuron damage. The toxin may also cause aortic aneurysm. A unique symptom of lathyrism is the atrophyof gluteal muscles

The lathyrism resulting from the ingestion of Lathyrus odoratus seeds (sweet peas or almorta, guija, pito, tito o alverjón in Spain or chícharos in Portugal is often referred to as odoratism or osteolathyrism, which is 
caused by a different toxin (beta-aminopropionitrile) that affects the linking of collagen, a protein of connective tissues.

Fava beans,Vicia faba, indeed, is a common human food in the Mediterranean regions of Europe. Their potential as a protein supplement for livestock is being explored in the U.S. and Canada.However, fava beans contain the glycosides vicine and covicine. These glycosides hamper the development of fava beans as a worldwide food and feed crop because they cause a disease called favism in people who have an inherited absence of the enzyme glucose-6-phosphate dehydrogenase (G6PD) in their red blood cells.

More than 100 million people worldwide are genetically deficient in G6PD, but it is well demontrated that chronic consumption of food or beverages containing vicine may drive to favism. People whose red blood cells are deficient in G6PD appear to be more resistant to the detrimental effects of maleria. Thus, this genetic condition is rarely found in populations with little historical exposure to maleria, but instead is concentrated in populations where malaria is prevalent. Susceptible people are exposed to favism either by inhaling the pollen of fava bean flowers or by eating the beans. In people who lack G6PD, divicine, the aglycone of vicine, and isouramil, the aglycone of covicine, cause acute hemolytic either by direct action on the red cell membranes or by producing hydrogen peroxide which in turn breaks down red cell membranes. The enzyme G6PD functions to maintain plentiful supplies of reduced glutathione. Oxidants such as divicine, isouramil, and hydrogen peroxide are normally reduced and rendered inactive by exposure to reduced glutathione. However, vulnerable individuals produce insufficient GSH to block the destruction of red cell membranes by these oxidants. The incidence of this genetic deficiency is as high as $50 \%$ in some populations. Prior to the advent of highly effective blood transfusion technology, mortality rates of 6 to $8 \%$ were reported in G6PD deficient children exposed to fava beans

Symptoms appear shortly after inhaling pollen but not until about 5 to 24 hours after eating the beans. They include headaches, dizziness, nausea, yawning, vomiting, abdominal pain, fever and finally an acute hemolytic anemia can occur.

The spark to draw up this study came from the fact thatcommon forage is advertised (especially in USA) to promote its sale for livestock feeding is too often represented as vicine-free and, meanwhilre on the othe hand the fact that too many papers disclaim the ability of certain enzymes that are in the rumen of herbivore stable animals, can distrupt vicine, let us think that there is something suspect in all this concern. Why should sellers propose a forage vicine-free, if this glycoside may be distrupted by the animal's rumen?

Some A.A. in 2007 (1), starting from the concept that the role of terrestrial vegetation in transferring chemicals from soil and air into specific plant tissues (e.g., stems, leaves, and roots) is still not well characterized, attempted to provide a critical review of plant-to-soil bioconcentration ratio (BCR) estimating these releationships on models and experimental data. Their article includes the conceptual and theoretical formulations of the BCR, constructing and calibrating empirical and mathematical algorithms to describe this ratio and the experimental data used to quantify BCRs and calibrate the model performance. They used as a case study, a single chemical, idest hexahydro-1,3,5- trinitro-1,3,5-triazine, and focused their attention on variability of bioconcentration measurements obtained from 81 experiments with different plant species, different plant tissues, different experimental conditions, and different methods for reporting concentrations in the soil and plant tissues. They finally used these observations to evaluate both the magnitude of experimental variability in plant bioconcentration and compare this to model uncertainty.

Chiou et al. [4] expressed the concentration of a contaminant in either the whole plant or a specific part of the plant the quasiequilibrium factor, describes the approach to equilibrium of any absorbed contaminant in the plant (or in a part of it) with respect to the same contaminant in soil solution; The A.A. publish the following Table I where some BCR values are plotted, in order to let understand how dangerous chemical pollutant (form soil or air) can penetrate by diverse ways inside certain parts of a herb or in the plant in toto.

Table I: some examples of the BCR of some parts of plants, cultivated in a milieu where air and soil were corrupted by a determined concentration of hexahydro-1,3,5- trinitro-1,3,5-triazine.

\begin{tabular}{|l|l|}
\hline Part of plant & BCR \\
\hline Bean fruit & 0.2 \\
\hline Lettuce leaves & 0.75 \\
\hline Bean stem & 1.22 \\
\hline Alfalfa seed & 1.25 \\
\hline Corn leaves & 4.22 \\
\hline Spinach root & 3.52 \\
\hline Tomato fruit & 5.50 \\
\hline Bean leaves & 19.32 \\
\hline Carrots shoot & 28.63 \\
\hline
\end{tabular}




\section{Materials and methods}

Vicine and convicine may be easily isolated from Faba vicia according two diverse methods and their presence can be detected by the usage of an UV spectrometer.(5)

Other methods are available, as HPLC or Foin Ciocolteau's reaction, but they are more laborious.

Our interest id focused on the presence of the vicine, and itsUV absorbance is at $274 \mathrm{~nm}$, when the solution of the sludge of leaves or unripe grapes or directly of the organic wine.

But twoare the methods described from the AA, as follows:

1) Sonication for five minutes of the juice of fresh leaves or unripe grape dissolved in deionised water and successive centrifugation (5500 rpm) for 5 minutes.

2) Extraction of the glycoside by the use of a trichloroacetic acid $2 \%$ owing to a centrifugation (5500 rpm) for 30 minutes.(pH must be 1) and thus according to accurated dilution in deionised water and reaching dverse values of $\mathrm{pH}$, detecting various shiftings of the peaks of the vicine (for instance at $\mathrm{pH} 6.8$ the peak will be $236 \mathrm{~nm})$

The samples were then measured at UV/vis spectrometer $(500-200 \mathrm{~nm})$ and the peak is undisputedly at $274 \mathrm{~nm}$. It is very easy to retrieve on line whichever spectra of vicine UV absorbance, especially in handbooks of forensic medicine, when there is the convinction that a corpse has been poisoned by the glycoside vicine, that is easily to be isolated using simple vinegar and this is a regular practice in Sardinia.

Peaks are similari $\mathrm{f}$ the solution is aqueous ( $\mathrm{pH} 6.8$ by phosphate buffer), acid, alkaline.

Several measures have been made even on wines that were NO organic (almost three samples) and in all cases a peak between 256 and 280 is always present.

\section{Results}

UV spectra effectuated on solution of sludge of fresh leaves or grapes and finally on organic wine, gine always a net peak at $274 \mathrm{~nm}$.

I haveeven supposed that these peaks were due to the presence of tannins, since their complicated chemical structure, are never simply detectable by UV rays, and generally their peaks are comprised among 280 and 290 $\mathrm{nm}$.

But there are several identification tests that assert if the soltution of wine does contain tannins and I made all these tests.

It is obvious that even organic wines come back positive to tests (since they do contain tannins equally), but I will explain the differences.

First test:

Adding a diluted solution of ferric chloride to an aqueous solution (1:5) of the organic unripe grape, leaves or wine, the colour drives to azure, meanwhile the tests effected onto no organic wines, the colour drives to black.This mean that the content of tannins is minimal in organic wine: the remnant is vicine.

If afterwards a solution of sulphuric acid is poured in the sample, a tawny-pecan brownish precipitate is formed in case of no organic wine.In organic wine the colour is just yellowish.

Second test:

If a solution of albumin is poured on the sample of the no organic wine, an evident coagulation appears.

If the coaugulated precipitate is left uncovered for three days, no putrescence appears.

If the precipitate of the organic wine is left uncovered for three days, it develops to a strong putrescence and becomes stinky.

Third test:

All tannins tend to evoke a chemical precipitation of wichever alkaloid, or satured solution of $\mathrm{NaCl}$ or sulphuric acid.

The mix of organic wine treated with TCA, provokes only a slight coalescence in presence of alkaloid, $\mathrm{NaCl}$ or sulphuric acid.

\section{Discussions and Conclusion}

It is mandatory to know gow the "organic" winegrower proceeds in his production, idest, which type of cover crop uses.

Vetch, lupins, field beans must not be present in forage for manuring vineyards.

I twill auspicable that in a future European Laws impose the rule to put in evidence on label of the bottle of organic wine if it has been treated with cover crops containing vicine. 


\section{References}

[1]. McKone TE, Maddalena RL;Plant uptake of organic pollutants from soil: bioconcentration estimates based on models and experiments.2007.Environ Toxicol Chem.;26(12):2494-504.

[2]. McKone TE:. The precision of QSAR methods for estimating intermedia transfer factors in exposure assessments. SAR and QSAR.1993: Environ Res 1:41-51.

[3]. McFarlane JC, Pfleeger T, Fletcher J;. Transpiration effect on the uptake and distribution of bromacil, nitrobenzene, and phenol in soybean plants.1987;. J Environ Qual 16:372-376.

[4]. Chiou CT, Sheng G, Manes M.;A partition-limited model for the plant uptake of organic contaminants from soil and water.2001;. Environ Sci Technol 35:1437-1444.

[5]. Ferhatoglu Y, Vandenberg A.;Re-evaluating TiCl4 and UV assays for detection of vicine and convicine in high-throughput screening of immature and mature seeds of faba bean.:2015. African Journal of Plant Science. . 9(12), pp. 476-489. 